\title{
POLITIK HUKUM TENTANG PERAN MAHKAMAH KONSTITUSI DALAM MELINDUNGI EKSISTENSI KESATUAN MASYARAKAT HUKUM ADAT DI INDONESIA
}

\section{LEGAL POLITICS ON THE ROLE OF THE CONSTITUTIONAL COURT IN PROTECTING THE EXISTENCE OF THE ADAT LAW SOCIETY IN INDONESIA}

\author{
Titis Anindyajati \\ Pusat Penelitian dan Pengkajian Perkara Mahkamah Konstitusi \\ Jalan Medan Merdeka Barat No. 6 Jakarta \\ titis_mh@yahoo.com
}

\begin{abstract}
The implementation of the communities' rights, including the right of the natural resources has not been consistent with the principles of the constitution, although the existences of entities of the adat law societies (Kesatuan Masyarakat Hukum Adat, or KMHA) have already recognised and guaranteed by the Constitution and have also been mentioned in various Laws regarding the natural resources. For that reason, the Constitutional Court through its decisions, which determines the legal policy of Constitutional Court exists to balance the power between the excecutives and the judicials. There are already various papers about the entities of the adat law societies, but none of it elaborate on how the Laws protects the rights of KMHA and the role of Constitutional Court in protecting its existences from the legal politics. Laws and regulations related to the rights of KMHA regarding the natural resources and Constitutional Courts decisions related to KMHA and the natural resources were used in this paper as research objects. In addition, a number of bibliography and primary law resources were also employed as the source of study. This research unveiled that since the issue of the Constitutional Court Decision No.35/PUU-X/2012, there have been numerous technical rules regulating the existence of KMHA explicitly. In the meantime, the Constitutional Court through its decisions, based on the philosophical, juridical and sociological considerations, have already produced landmark decisions regarding the important limitations to define KMHA. This was one of the main role of Constitutional Court to uphold the principles of Constitution.
\end{abstract}

Keywords: politics of law, The Constitutional Court of Indonesia, the entities of the adat law societies

\begin{abstract}
Abstrak
Sejatinya pelaksanaan hak-hak KMHA, khususnya hak-hak di bidang Sumber Daya Alam (SDA) belum sejalan dengan amanat konstitusi, walaupun keberadaan Kesatuan Masyarakat Hukum Adat (KMHA) telah ditegaskan dalam konstitusi dan diturunkan melalui peraturan perundang-undangan terkait Sumber Daya Alam (SDA). Untuk itulah Mahkamah Konstitusi melalui putusan-putusannya yang melahirkan Politik Hukum Mahkamah Konstitusi hadir untuk menyeimbangkan kekuasaan antara eksekutif dan yudikatif. Penulisan tentang Masyarakat Hukum Adat sudah banyak, namun belum ada yang lebih spesifik menulis tentang bagaimana Peraturan perundang-undangan mengatur hak-hak Kesatuan Masyarakat Hukum Adat (KMHA) dan bagaimana kontribusi Mahkamah Konstitusi dalam melindungi eksistensi KMHA dari aspek politik hukum. Peraturan Perundang-undangan yang terkait dengan hak-hak KMHA di bidang Sumber Daya Alam dan Putusan-Putusan Mahkamah Konstitusi yang terkait dengan KMHA dan Sumber Daya Alam khususnya digunakan sebagai objek penelitian serta meneliti bahan-bahan pustaka dalam menganalisis dan mengkaji bahan hukum. Dalam penelitian ini ditemukan bahwa sejak adanya Putusan MK No.35/PUU-X/2012, banyak muncul peraturan-peraturan teknis yang mengatur lebih tegas tentang keberadaan KMHA. Sementara itu, Politik Hukum Mahkamah Konstitusi melalui putusan-putusannya yang berlandaskan filosofis, yuridis dan sosiologis melahirkan landmark decision mengenai batasan penting untuk mendefinisikan KMHA. Hal ini merupakan salah satu peran Mahkamah dalam menjalankan amanat konstitusi.
\end{abstract}

Kata kunci: politik hukum, Mahkamah Konstitusi, Kesatuan Masyarakat Hukum Adat (KMHA) 


\section{Pengantar}

Sejatinya, kesatuan Masyarakat Hukum Adat memiliki berbagai istilah atau penyebutan, misalnya saja Van Vollenhoven dan Soepomo (Tolib Setiady, 2013:75) menggunakan istilah Persekutuan Hukum Adat (Adatrechts Gemeenschapen), Ter Haar dan Hazairin (Tolib Setiady, 2013:76) memakai istilah Masyarakat Hukum Adat, atau istilah-istilah lain seperti masyarakat tradisional, desa dan sebagainya. Namun demikian, hakikatnya Kesatuan Masyarakat Hukum Adat (MHA) menjadi satu kesatuan yang tidak terpisahkan dengan masyarakat Indonesia umumnya.

Istilah Kesatuan Masyarakat Hukum Adat (selanjutnya disebut KMHA) adalah istilah resmi yang tercantum dalam berbagai peraturan perundang-undangan, seperti dalam UndangUndang Nomor 5 Tahun 1960 Tentang Peraturan Dasar Pokok-Pokok Agraria (yang selanjutnya disebut UUPA), Undang-Undang Nomor 41 Tahun 1999 Tentang Kehutanan, UndangUndang Nomor 39 Tahun 2014 Tentang Perkebunan dan peraturan perundang-undangan lainnya sebagai padanan dari rechtgemeenschapt, atau oleh sedikit literatur menyebutnya adatrechtgemenschap. Menurut Abdurrahman (Abdurrahman, 2015:12), Istilah Kesatuan Masyarakat Hukum Adat dilahirkan dan digunakan oleh pakar hukum adat yang lebih banyak difungsikan untuk keperluan teoritik akademis. Sedangkan istilah masyarakat adat adalah istilah yang lazim diungkapkan dalam bahasa sehari-hari oleh kalangan non hukum yang mengacu pada sejumlah kesepakatan internasional.

Setelah mengalami perubahan pasca reformasi tahun 1999, Undang-Undang Dasar 1945 mengakomodir dan menegaskan keberadaan Kesatuan Masyarakat Hukum Adat melalui rumusan Pasal 18B ayat (2) UUD 1945 yang menyatakan bahwa negara mengakui dan menghormati kesatuan-kesatuan Kesatuan Masyarakat Hukum Adat (KMHA) beserta hak-hak tradisionalnya sepanjang masih hidup dan sesuai dengan perkembangan masyarakat dan prinsip negara kesatuan Republik Indonesia, yang diatur dalam undang-undang. Pasal 18B ayat (2) UUD 1945 tersebut diperkuat dengan ketentuan pasal 281 ayat (3) UUD 1945 yang menyatakan bahwa identitas budaya dan masyarakat tradisional dihormati. Norma inilah yang kemudian menjadi landasan konstitusional pengakuan Kesatuan Masyarakat Hukum Adat di Indonesia.

Walaupun demikian, fakta di lapangan menunjukkan bahwa pembangunan serta modernisasi cenderung tidak berpihak kepada kesejahteraan masyarakat adat. Sebagian besar komunitas masyarakat hukum adat menjadi miskin dan tertindas karena ketimpangan penguasaan sumber-sumber kehidupan. Industrialisasi dan komersialisasi yang berujung pada perizinan terhadap eksplorasi dan eksploitasi alam berdampak pada teralihkannya hak-hak masyarakat adat kepada pihak pemodal atau pengusaha. Tidak jarang terjadi perampasan tanah masyarakat adat untuk kemudian dijadikan perkebunan sawit, pertambangan, objek konsesi kehutanan dan konservasi. Tidak sedikit komunitas masyarakat adat terlibat konflik dengan perusahaan yang merampas wilayah kehidupan mereka. Dalam menghadapi konflik, seringkali masyarakat adat terhalangi oleh sistem hukum yang tidak mendukung keberadaan mereka. Bahkan, hukum adat, berikut praktekpraktek penyelesaian sengketa dalam masyarakat adat, dicap sebagai praktek yang bertentangan dengan hukum, dan karenanya penyelesaian sengketa masyarakat adat harus tunduk pada ketentuan hukum negara melalui mekanisme peradilan formal negara. Selain itu, sistem pengurusan diri (pemerintahan adat) oleh negara dipandang tidak sesuai lagi dengan perkembangan masyarakat dan karenanya perlu diseragamkan.

Sementara itu, lemahnya pengakuan Kesatuan Masyarakat Hukum Adat sebagai subyek hukum yang mempunyai hak-hak khusus dan istimewa turut berperan kepada maraknya pelanggaran-pelanggaran terhadap hak-hak KMHA yang dilakukan oleh negara. Beberapa peraturan perundang-undangan belum cukup melindungi keberadaan Kesatuan Masyarakat Hukum Adat dan belum dijalankan dengan baik. Pasal 18B ayat (2) UUD 1945 mengamanatkan adanya ketentuan yang lebih implementatif terhadap pengakuan Kesatuan Masyarakat Hukum Adat, namun politik hukum yang terlihat seolah hanya mengakomodir Kesatuan Masyarakat Hukum Adat semata-mata dalam undang-undang yang berkaitan dengan sumber daya alam dengan posisi tawar yang tidak signifikan. Sulitnya mendapatkan dasar hukum yang jelas mengenai pengakuan Kesatuan Masyarakat Hukum Adat serta belum adanya mekanisme yang mengintegrasikan perangkat adat dalam sistem hukum formal dapat mempersulit masyarakat 
adat mendapatkan posisi tawar yang lebih baik khususnya dalam penguasaan dan pengelolaan sumber daya.

Saat ini telah banyak undang-undang yang mengatur tentang keberadaan dan hak-hak KMHA, namun penyebutan KMHA ini lebih banyak dimunculkan dalam rumusan undangundang di bidang sumber daya alam. Pengaturan SDA yang tertuang dalam UU SDA/Sektoral sebagian besar lebih berpihak pada swasta menjadi salah satu penyebab terbesar konflik dan sengketa penguasaan/kepemilikan antara Negara dan/atau swasta sebagai pihak yang berkuasa dan masyarakat sebagai pihak yang dikuasai.

Beberapa persoalan lain terkait pengaturan KMHA yaitu beberapa undangundang tersebut lebih didominasi oleh norma yang mengatur dan membatasi, bahkan cenderung 'merampas' hak-hak masyarakat adat akan sumber daya alam, bukan norma yang berorientasi pada pengakuan dan perlindungan hak masyarakat adat. Dapat dikatakan undangundang yang ada saat ini belum sepenuhnya berpihak kepada KMHA ataupun memenuhi amanat konstitusi, khususnya Pasal 18B ayat (2) UUD 1945.

Hadirnya Mahkamah Konstitusi sebagai salah satu lembaga kekuasaan kehakiman diharapkan dapat menjadi pelindung hak-hak SDA Kesatuan Masyarakat Hukum Adat (KMHA) melalui Pengujian UU terhadap UUD 1945 mengingat KMHA telah diakui sebagai subjek hukum dewasa ini. Konstitusi melalui Mahkamah Konstitusi membuka celah bagi masyarakat hukum adat untuk mempertahankan hak-hak konstitusionalnya yang terlanggar sebagai perwujudan dari Negara demokratis. Dalam teori kontrak Sosial oleh Jean Jacque Rousseau (Wignjosoebroto, 2002:419) dikatakan bahwa kehidupan Negara demokratis sejatinya terwujud dari kontrak-kontrak sosial antara Negara dan warga nya yang bersedia sebagian hak-haknya "ditidurkan" demi terciptanya tambahan kekuasaan pengatur oleh pemerintah. Namun demikian, hak-hak yang ditidurkan tersebut tidaklah termasuk dalam hak-hak konstitusional kesatuan masyarakat hukum adat.

Secara umum, hak-hak konstitusional KMHA diatur dalam Pasal 18B dan Pasal 28I ayat (3) UUD 1945. Pasal-pasal a quo sejatinya merupakan pengejawantahan dari peran dan kewajiban Negara untuk melindungi, mengakui dan menghormati hak-hak Kesatuan Masyarakat
Hukum Adat di Indonesia. Menurut Jimly Asshiddiqie (Asshidiqie, 2003:32-33), Pasal 18B ayat (2) memiliki makna bahwa Negara mengakui (i) Eksistensi suatu Kesatuan Masyarakat Hukum Adat beserta hak-hak tradisional yang dimilikinya; (ii) Eksistensi yang diakui adalah eksistensi kesatuan-kesatuan Kesatuan Masyarakat Hukum Adat; (iii) Kesatuan Masyarakat Hukum Adat itu memang hidup (masih hidup); (iv) Dalam lingkungannya (lebensraum) yang tertentu pula; (v) Pengakuan dan penghormatan itu diberikan tanpa mengabaikan ukuran-ukuran kelayakan bagi kemanusiaan sesuai dengan tingkat perkembangan keberadaan bangsa; (vi) pengakuan dan penghormatan itu tidak boleh mengurangi makna Indonesia sebagai negara yang berbentuk negara kesatuan Republik Indonesia. Mahkamah Konstitusi (MK) sebagai lembaga yang salah satu kewenangannya adalah untuk judicial review juga berkontribusi dalam mendukung usaha-usaha pengakuan terhadap KMHA dan pembenahan terhadap sistem hukum. Bahkan salah satu kontribusi terbesar MK melalui Undang-Undang Mahkamah Konstitusi (UU No.24/2003 sebagaimana diubah dengan UU No.8/2011) memberikan pengakuan terhadap Kesatuan Masyarakat Hukum Adat sebagai salah satu subjek hukum untuk menjadi pemohon di Mahkamah Konstitusi dalam perkara judicial review. Hal ini diatur dalam Pasal 51 ayat 1 huruf (b) yang menyatakan, syarat Pemohon untuk mengajukan permohonan pengujian undang-undang terhadap UUD 1945 adalah bahwa Pemohon haruslah termasuk dalam salah satu dari subjek hukum yang menganggap hak dan/atau kewenangan konstitusionalnya dirugikan oleh berlakunya undang-undang yang dimohonkan pengujian, yaitu:

(1) Perorangan warga negara Indonesia;

(2) Kesatuan Kesatuan Masyarakat Hukum Adat sepanjang masih hidup dan sesuai dengan perkembangan masyarakat dan prinsip Negara Kesatuan Republik Indonesia yang diatur dalam undang-undang.

Kontribusi MK lainnya yaitu pada Putusan MK No.35/PUU-X/2012 tentang Pengujian Undang-Undang Kehutanan. Dalam putusan a quo, MK mengembalikan hak-hak Kesatuan Masyarakat Hukum Adat dalam kasus kepemilikan hutan adat yang selama ini digolongkan sebagai hutan Negara menjadi hutan hak oleh KMHA. Putusan ini menjadi salah satu tonggak penegakan hak-hak konstitusional KMHA yang selama ini terlanggar 
khususnya dalam UU Kehutanan. Putusan MK tersebut membangunkan kesadaran baik dari pihak pemerintah maupun KMHA sendiri untuk membentuk produk-produk hukum khususnya yang bersifat lebih teknis sebagai landasan hukum dalam melindungi hak-hak KMHA.

Berdasarkan latar belakang tersebut maka sangat diperlukan pembahasan yang mendalam mengenai bagaimana undang-undang mengatur pengakuan dan perlindungan terhadap Kesatuan Masyarakat Hukum Adat dalam sistem hukum nasional yaitu UU terkait Sumber Daya Alam. Selain itu, terkait fungsinya sebagai lembaga pengawal konstitusi yang melindungi hak-hak konstitusional warga negaranya, perlu dikaji bagaimanakah peran MK dalam menegaskan dan melindungi pengakuan Kesatuan Masyarakat Hukum Adat sesuai amanat UUD 1945 sebagai konstitusi Indonesia. Tulisan ini mendiskusikan,

(a) Bagaimanakah perlindungan Hak-hak Kesatuan Masyarakat Hukum Adat (KMHA) dalam Peraturan Perundang-undangan khususnya UU SDA?; serta

(b) Bagaimanakah Peran Mahkamah Konstitusi dalam Politik Hukum Perlindungan Kesatuan Masyarakat Hukum Adat (KMHA) di Indonesia?

\section{Metode Penelitian}

Penelitian ini merupakan penelitian doctrinal yang meneliti melalui bahan hukum primer, sekunder dan tertier yang sesuai dengan objek penelitian. Penelitian ini lebih mengutamakan studi pustaka (library research) dengan mengkaji bahan hukum, baik yang bersifat primer, sekunder maupun tersier. Penelitian studi pustaka dilakukan dengan mengumpulkan, menelusuri dan mensistemasikan bahan-bahan terkait yang diperlukan dalam penelitian ini. Bahan hukum primer penelitian ini adalah UUD 1945 sebagai norma atau kaidah dasar dan Peraturan Perundang-undangan yang berkaitan khususnya UU Sumber Daya Alam. Untuk mendapatkan data sekunder akan dilakukan melalui penelitian kepustakaan (library research) dengan menggunakan studi dokumenter terhadap referensi-referensi yang relevan dengan objek penelitian yang didapatkan dari peraturan perundang-undangan, buku dan artikel serta dalam kamus dan ensiklopedia. Bahan hukum tersier berupa dokumen yang berisi konsep-konsep dan keterangan-keterangan yang mendukung bahan hukum primer dan bahan hukum sekunder seperti kamus, ensiklopedia, dan lain-lain.

Adapun analisis telah dilakukan melalui dua tahapan. Pertama, analisis normatif dilakukan dengan cara melakukan tinjauan atas pasal-pasal yang terkait dengan Hak-hak Kesatuan Masyarakat Hukum Adat (MHA) dalam konstitusi, seperti ketentuan Pasal 18B ayat (2) dan Pasal 28I ayat (3) UUD 1945 dan dalam peraturan perundang-undangan terkait UU Sumber Daya Alam, misalnya Kehutanan, UU Perkebunan, dan lain-lain. Kemudian analisis dilakukan dengan menelusuri putusan-putusan MK terkait KMHA yang menjadi landmark decision khususnya Putusan MK yang mengabulkan untuk mengetahui Kebijakan Hukum Pemerintah Indonesia secara nasional (Politik Hukum) tentang Peranan MK terhadap eksistensi KMHA.

\section{Perlindungan Hak-hak Kesatuan Masyarakat Hukum Adat (MHA) dalam Peraturan Perundang-undangan di Indonesia}

Pengakuan Kesatuan Masyarakat Hukum Adat secara tegas muncul dalam perubahan Kedua UUD 1945 pada tanggal 18 Agustus 2000 di mana tercantum dalam Ketentuan Pasal 18B ayat (2) UUD 1945 yang menyatakan, "Negara mengakui dan menghormati kesatuan-kesatuan Kesatuan Masyarakat Hukum Adat beserta hakhak tradisionalnya sepanjang masih hidup dan sesuai dengan perkembangan masyarakat dan prinsip Negara Kesatuan Republik Indonesia, yang diatur dalam Undang-undang". Menurut Jimly Asshiddiqie (Asshiddiqie,2015:358-359), pengakuan masyarakat hukum adat dalam Pasal 18B ayat (2) UUD 1945 tidak hanya melahirkan masyarakat hukum adat sebagai subjek hukum yang menyandang hak-hak dan kewajibankewajiban dalam lalu lintas hukum namun juga pengakuan dan penegasan unit organisasi dan hak-hak tradisional masyarakat hukum adat dalam wilayah tradisional Kesatuan Masyarakat Hukum Adat yang bersangkutan. Dengan demikian, KMHA di Indonesia telah mendapatkan hak sekaligus kewajibannya sebagai subjek hukum sehingga berakibat pada dua sisi yaitu bagaimana KMHA wajib menaati peraturan yang berlaku di Indonesia yaitu hukum nasional dan bagaimana KMHA tetap melestarikan dan menjalankan kebiasaan-kebiasaan yang juga telah menjadi hukum yang berlaku secara adat dalam lingkungan KMHA itu sendiri. 
Sementara itu, mengacu pada UU No.12 Tahun 2011 tentang Pembentukan Peraturan Perundang-undangan, jenis dan hirarki peraturan perundang-undangan RI sebagai berikut:

(a) UUD Negara Republik Indonesia Tahun 1945 ;

(b) Ketetapan MPR;

(c) UU/Perppu;

(d) Peraturan Pemerintah;

(e) Peraturan Presiden;

(f) Peraturan Daerah Provinsi;

(g) Peraturan Daerah Kabupaten/Kota.

Dalam penulisan ini, peraturan perundang-undangan yang dimaksud yaitu beberapa UU khususnya UU terkait sektoral/ Sumber Daya Alam yang mengatur tentang hakhak KMHA. Beberapa undang-undang khususnya undang-undang sektoral telah mengakui dan mengatur hak-hak Kesatuan Masyarakat Hukum Adat. Undang-undang itu, antara lain: (1). UU Nomor 5 Tahun 1960 Tentang Peraturan Dasar Pokok-pokok Agraria (UUPA); (2). UU Nomor 41 Tahun 1999 Tentang Kehutanan; (3). UU Nomor 26 Tahun 2007 Tentang Penataan Ruang; (4). UU Nomor 32 Tahun 2009 Tentang Perlindungan dan Pengelolaan Lingkungan Hidup; (5). UU Nomor 18 Tahun 2013 tentang Pencegahan dan Pemberantasan Perusakan Hutan; (6). UU Nomor 6 Tahun 2014 Tentang Desa; (7). UU Nomor 23 Tahun 2014 Tentang Pemerintahan Daerah; (8). UU Nomor 39 Tahun 2014 Tentang Perkebunan.

Sejatinya, undang-undang yang merupakan hukum tertulis merupakan wahana atau jembatan antar lingkup aneka adat dan hukum tidak tertulis lainnya atau untuk mengatasi kebutuhan kepastian hukum tidak tertulis dalam hal pihakpihak menghendakinya (Indrati,2007:2). Untuk itu, undang-undang sebagai peraturan perundangundangan yang dibentuk DPR dengan persetujuan bersama Presiden diperlukan guna mewujudkan cita-cita dan tujuan-tujuan negara yaitu melindungi segenap bangsa Indonesia dan seluruh tumpah darah Indonesia serta memajukan kesejahteraan umum. Adanya unsur dan pengaturan hak-hak MHA dalam beberapa UU Sektoral menunjukkan adanya pengakuan dan penghormatan terhadap hak-hak MHA.

Undang-undang juga merupakan produk hukum yang bersumber dari politik hukum. Menyitir pendapat Utrecht (Sodiki, 2012:1) yang menyatakan bahwa politik hukum menyelidiki perubahan-perubahan apa yang harus diadakan dalam hukum yang sekarang berlaku agar sesuai dengan sociale werkelijkheid (kenyataan sosial). Oleh karena itu, politik hukum yang dibangun idelanya merupakan cerminan dari atau mempunyai tujuan untuk kepentingan masyarakat dan bukan kepentingan golongan tertentu. Kenyataan-kenyataan yang ada di lapangan, masih ditemukan undang-undang yang dirumuskan kurang sesuai dengan kehendak masyarakat khususnya KMHA. Hal ini dapat dilihat dari beberapa undang-undang terkait KMHA yang pernah diuji materiilkan ke MK salah satunya Perkara No.35/PUU-X/2012 tentang UU Kehutanan. Disinilah peran masyarakat khususnya KMHA menjadi penting dalam sistem ketatanegaraan Indonesia tidak hanya ikut serta dalam pembentukan peraturan perundang-undangan tetapi juga dalam menegakkan hak-hak konstitusional masyarakat itu sendiri.

Hal ini dapat dilihat pada Perkara Nomor 35/PUU-X/2012 tentang pengujian UU No.4/1999 tentang Kehutanan di Mahkamah Konstitusi. Salah satu Pemohon dalam perkara tersebut menyebut dirinya sebagai Kesatuan Masyarakat Hukum Adat Kenegerian Kuntu yang berada di Kabupaten Kampar, Provinsi Riau dan kesatuan Kesatuan Masyarakat Hukum Adat Kasepuhan Cisitu Banten Kidul Di Kabupaten Lebak.

Para pemohon mendalilkan bahwa UU Kehutanan memperlakukan Kesatuan Masyarakat Hukum Adat yang secara konstitusional sebagai subjek Hukum terkait dengan hutan berbeda dengan subjek hukum yang lain, dalam hal ini terkait dengan kategorisasi hutan yang di dalamnya terdapat hubungan hukum antara subjek hukum dengan hutan. Ada tiga subjek hukum yang diatur dalam UU Kehutanan, yakni negara, Kesatuan Masyarakat Hukum Adat, dan pemegang hak atas tanah yang di atasnya terdapat hutan. Negara menguasai baik atas tanah maupun atas hutan. Pemegang hak atas tanah dimaksud juga memegang hak atas hutan, tetapi untuk Kesatuan Masyarakat Hukum Adat tidak secara jelas pengaturan tentang haknya atas tanah maupun hutan. Definisi hutan adat [vide Pasal 1 angka 4 UU Kehutanan] sebagai hutan negara yang berada di atas tanah dalam wilayah MHA bertentangan dengan pemaknaan hutan negara [vide Pasal 1 angka 5 UU Kehutanan] yaitu hutan yang berada di atas tanah yang tidak dibebani suatu hak atas tanah. Hal ini tentu saja 
merugikan MHA karena negara dapat memberikan hak di atas tanah hak ulayat kepada subjek hukum tertentu tanpa ada persetujuan dari MHA dan kewajiban hukum membayar kompensasi kepada MHA yang memiliki hak atas tanah ulayat tersebut.

Untuk itulah kemudian Pemohon menginginkan agar MK untuk menguji norma dalam Undang-Undang Kehutanan yang dianggap merugikan atau setidaknya menyampingkan hak masyarakat hukum adat, karena pengujian undang-undang merupakan salah satu jalan untuk mengubah apa yang telah ditetapkan legislator di dalam undang-undang dan untuk menjawab pertanyaan terhadap konstitusionalitas norma tersebut.

Terhadap permasalahan pembedaan perlakuan antara MHA dengan subjek hukum lain, Mahkamah berpendapat keberadaan hutan adat dalam kesatuannya dengan wilayah hak ulayat dari suatu masyarakat hukum adat adalah konsekuensi pengakuan terhadap hukum adat sebagai "living law". Dalam kenyataannya, hutan adat merupakan bagian dari wilayah hak ulayat sehingga hak pengelolaan hutan adat berada pada MHA dan menjadi hak Pemerintah apabila dalam perkembangannya MHA yang bersangkutan tidak ada lagi [vide Pasal 5 ayat (4) UU kehutanan].

Untuk menghindari adanya tumpang tindih antara wewenang negara dan wewenang hak MHA yang terkait hutan maka wewenang hak ulayat dibatasi seberapa jauh isi dari wewenang hak perseorangan, sedangkan wewenang negara dibatasi sejauh isi dan wewenang hak ulayat atau dengan kata lain negara hanya mempunyai wewenang secara tidak langsung terhadap hutan adat. Terhadap hutan adat, wewenang negara dibatasi sejauh mana isi wewenang yang tercakup dalam hutan adat. Hutan adat (yang disebut pula hutan marga, hutan pertuanan, atau sebutan lainnya) berada dalam cakupan hak ulayat karena berada dalam satu kesatuan wilayah (ketunggalan wilayah) masyarakat hukum adat, yang peragaannya didasarkan atas leluri (traditio) yang hidup dalam suasana rakyat (in de volksfeer) dan mempunyai suatu badan perurusan pusat yang berwibawa dalam seluruh lingkungan wilayahnya. Para warga suatu masyarakat hukum adat mempunyai hak membuka hutan ulayatnya untuk dikuasai dan diusahakan tanahnya bagi pemenuhan kebutuhan pribadi dan keluarganya. Dengan demikian, tidak dimungkinkan hak yang dipunyai oleh warga masyarakat hukum adat tersebut ditiadakan atau "dibekukan" sepanjang memenuhi syarat dalam cakupan pengertian kesatuan masyarakat hukum adat sebagaimana dimaksud dalam Pasal 18B ayat (2) UUD 1945. Oleh karena itu, menempatkan hutan adat sebagai bagian dari hutan negara merupakan pengabaian terhadap hak-hak masyarakat hukum adat. Definisi hutan adat dalam Pasal 1 angka 6 UU Kehutanan menghilangkan kata "negara" yang dianggap bertentangan dengan konstitusi sehingga menjadi "Hutan Adat adalah hutan yang berada dalam wilayah masyarakat hukum adat".

Selain itu, para pemohon juga mengujikan ketentuan Pasal 4 ayat (3) UU Kehutanan karena membatasi hak-hak masyarakat hukum adat untuk memanfaatkan hasil kekayaan alam yang berada di wilayah adatnya. Terhadap pengujian tersebut, sebelumnya Mahkamah pernah memutus dalam Putusan Nomor 34/PUUIX/2011 bertanggal 16 Juli 2012. Mahkamah berpendapat Pasal 4 ayat (3) UU Kehutanan bertentangan dengan UUD 1945 sepanjang tidak dimaknai, "Penguasaan hutan oleh negara tetap wajib melindungi, menghormati, dan memenuhi hak masyarakat hukum adat, sepanjang kenyataannya masih ada dan diakui keberadaannya, hak masyarakat yang diberikan berdasarkan ketentuan peraturan perundangundangan, serta tidak bertentangan dengan kepentingan nasional" (vide Putusan Mahkamah Konstitusi Nomor 34/PUU-IX/2011 bertanggal 16 Juli 2012, paragraf [3.16.2]). Walaupun demikian, Mahkamah menilai alasan konstitusional permohonan pengujian dalam permohonan para Pemohon terhadap pasal a quo berbeda sehingga Mahkamah mempertimbangkan kembali pengujian a quo.

Menurut Mahkamah, UUD 1945 telah menjamin keberadaan KMHA beserta hak-hak tradisionalnya sepanjang masih hidup dan sesuai dengan perkembangan masyarakat dan prinsip Negara Kesatuan Republik Indonesia yang diatur dengan Undang-Undang dalam Pasal 18B ayat (2) UUD 1945. Sekalipun disebut masyarakat hukum adat, masyarakat demikian bukanlah masyarakat yang statis. Gambaran masyarakat hukum adat masa lalu untuk sebagian, kemungkinan besar telah mengalami perubahan pada masa sekarang. Bahkan masyarakat hukum adat dengan hak ulayatnya di berbagai tempat, lebih-lebih di daerah perkotaan sudah mulai 
menipis dan ada yang sudah tidak ada lagi. Masyarakat demikian telah berubah dari masyarakat solidaritas mekanis menjadi masyarakat solidaritas organis. Dalam masyarakat solidaritas mekanis hampir tidak mengenal pembagian kerja, mementingkan kebersamaan dan keseragaman, individu tidak boleh menonjol, pada umumnya tidak mengenal baca tulis, mencukupi kebutuhan sendiri secara mandiri (autochton), serta pengambilan keputusan-keputusan penting diserahkan kepada tetua masyarakat (primus interpares). Di berbagai tempat di Indonesia masih didapati masyarakat hukum yang bercirikan solidaritas mekanis. Masyarakat demikian merupakan unikum-unikum yang diakui keberadaannya (rekognisi) dan dihormati oleh UUD 1945. Sebaliknya masyarakat solidaritas organis telah mengenal berbagai pembagian kerja, kedudukan individu lebih menonjol, hukum lebih berkembang karena bersifat rational yang sengaja dibuat untuk tujuan yang jelas.

Kata "memperhatikan" dalam Pasal 4 ayat (3) UU Kehutanan harus dimaknai lebih tegas, yaitu negara mengakui dan menghormati kesatuan-kesatuan masyarakat hukum adat beserta hak-hak tradisionalnya, sejalan dengan maksud Pasal 18B ayat (2) UUD 1945. Adapun syarat pengakuan dan penghormatan masyarakat hukum adat dalam frasa "sepanjang kenyataannya masih ada dan diakui keberadaannya", harus dimaknai sepanjang masih hidup dan sesuai dengan perkembangan masyarakat, karena hukum adat pada umumnya merupakan hukum yang tidak tertulis dan merupakan living law, artinya merupakan hukum yang diterima (accepted) dan dijalankan (observed) serta ditaati oleh masyarakat yang bersangkutan karena memenuhi rasa keadilan bagi mereka dan sesuai serta diakui oleh konstitusi.

Untuk mencegah terjadinya dampak negatif, UUD 1945 memerintahkan keberadaan dan perlindungan kesatuan-kesatuan masyarakat hukum adat supaya diatur dalam UndangUndang, agar dengan demikian menjamin adanya kepastian hukum yang berkeadilan. Oleh karena itu, Pasal 4 ayat (3) UU Kehutanan bertentangan dengan UUD 1945 secara bersyarat (conditionally unconstitutional), sehingga tidak mempunyai kekuatan hukum mengikat, kecuali dimaknai bahwa "penguasaan hutan oleh negara tetap memperhatikan hak masyarakat hukum adat, sepanjang masih hidup dan sesuai dengan perkembangan masyarakat dan prinsip Negara Kesatuan Republik Indonesia yang diatur dalam undang-undang".

Dengan demikian, pengaturan hak-hak KMHA dalam UU khususnya UU sektoral/SDA masih sebatas pengakuan saja dan baik secara normatif maupun implentatif atau penegakan hukum masih lemah dan belum berpihak pada KMHA. Untuk itu sebenarnya perlu ada pengaturan yang lebih khusus dan spesifik tidak hanya dari hak saja tetapi secara keseluruhan tentang KMHA demi melindungi eksistensi KMHA.

\section{Politik Hukum tentang Peranan Mahkamah Konstitusi terhadap Kesatuan Masyarakat Hukum Adat (KMHA) di Indonesia}

Sebagai negara hukum, Indonesia menganut prinsip supremasi konstitusi dimana posisi konstitusi menempati kedudukan tertinggi dalam tertib Hukum Indonesia. Hukum adat yang menjadi pijakan Kesatuan Masyarakat Hukum Adat menjadi salah satu alas politik hukum pada sistem hukum nasional. Idealnya, unsur-unsur Sistem Hukum Nasional di Indonesia saling menunjang satu sama lain dan bersesuaian serta dapat berkembang sesuai kebutuhan masyarakat Indonesia.

Namun demikian tidak dapat dinegasikan apabila hukum yang berdinamika terkadang bersinggungan dengan politik hukum. Menyitir pendapat William Zevenbergen (Latif dan Ali, 2014:19), Perundang-undangan merupakan bentuk politik hukum (legal policy). Politik hukum mencoba menjawab pertanyaan, peraturanperaturan hukum mana yang patut untuk dijadikan hukum. Pengertian legal policy mencakup proses pembuatan dan pelaksanaan hukum yang dapat menunjukkan sifat dan ke arah mana hukum akan dibangun. Dengan kata lain, politik hukum memberikan landasan terhadap proses pembentukan hukum yang lebih sesuai, situasi dan kondisi, kultur, serta nilai yang berkembang di masyarakat dengan memperhatikan kebutuhan masyarakat terhadap hukum itu sendiri. Manusia sebagai individu dan masyarakat secara kolektif sejatinya merupakan zoon politicon (makhluk bertata pemerintahan) sehingga menjadi lazim apabila kebutuhan masyarakat menjadi salah satu acuan dalam politik hukum.

Sementara itu, Politik hukum dapat dibedakan menjadi dua dimensi. Pertama, politik hukum yang menjadi alasan dasar dari 
diadakannya suatu peraturan perundangundangan. Kedua, tujuan atau alasan yang muncul dibalik pemberlakuan suatu peraturan perundang-undangan. Untuk itulah politik hukum memiliki peranan sangat penting dalam pembentukan peraturan perundang-undangan. Pertama, sebagai alasan mengapa diperlukan pembentukan suatu peraturan perundangundangan. Kedua, untuk menentukan apa yang hendak diterjemahkan ke dalam kalimat hukum dan menjadi perumusan pasal. Dua hal ini penting karena keberadaan peraturan perundangundangan dalam perumusan pasal merupakan jembatan antara politik hukum tersebut dalam tahap implementasi peraturan perundangundangan. Hal ini mengingat antara pelaksanaan peraturan perundang-undangan harus ada konsistensi dan korelasi erat dengan apa yang ditetapkan sebagai politik (Latif dan Ali, 2014: 19). Dengan demikian, peraturan perundangundangan tidak dapat dilepaskan dari politik hukum itu sendiri dimana undang-undang itu sendiri tidak jarang menimbulkan konflik dalam memperebutkan kepentingan, hak dan kewajiban antara para pihak pemangku. Untuk itulah, keberadaan Mahkamah Konstitusi diperlukan sebagai penyeimbang kekuasaan antara kekuasaan legislatif dan kekuasaan eksekutif.

Berbicara tentang Politik hukum pembentukan Mahkamah Konstitusi, terbentuknya Mahkamah Konstitusi dapat dilihat dalam 2 (dua) perspektif yaitu politik dan hukum (Tim Penyusun Hukum Acara MK, 2010:25). Keberadaaan MK RI ditinjau dari aspek politik ketatanegaraan untuk mengimbangi kekuasaan pembentukan undang-undang yang dimiliki oleh DPR dan Presiden. Sedangkan dalam aspek hukum, keberadaan MK menjadi salah satu konsekuensi perubahan dari supremasi MPR menjadi supremasi konstitusi, prinsip negara kesatuan, prinsi demokrasi dan prinsip Negara Hukum.

Selain itu, mengacu pada ketentuan Pasal 3 ayat (1) UU No.12/2011, Undangundang Dasar Tahun 1945 dalam hierarki atau tata urutan peraturan perundangan merupakan hukum dasar pembentukan peraturan perundangundangan. UUD 1945 juga mempunyai fungsi sebagai alat kontrol dan menentukan keabsahan agar suatu norma hukum dalam undang-undang tidak bertentangan dengan ketentuan UUD 1945. Agar ketentuan hukum di bawah konstitusi tidak bertentangan dengan kostitusi, maka akan dilakukan pengujian undang-undang terhadap
UUD 1945. Kewenangan pengujian ini sangat diperlukan karena salah satu ukuran yang paling mendasar adalah ada atau tidaknya pelanggaran terhadap hak konstitusional yang ditentukan dalam UUD 1945 menjadi aturan hukum undang-undang sebagai dasar penyelenggaraan negara. Untuk itu, dibentuklah MKRI melalui Perubahan Ketiga UUD 1945 yang tercantum dalam Pasal 24 ayat (2), Pasal 24C, dan Pasal 7B UUD 1945 (Tim Penyusun Hukum Acara MK,2010:8).

Walaupun Kesatuan Masyarakat Hukum Adat telah diakui sebagai subjek hukum khususnya sebagai Pemohon dalam ketentuan Pasal 51 ayat (1) huruf b UU MK, dalam praktiknya Mahkamah menguraikan kembali pemaknaan dan kriteria kesatuan MHA. Dalam pengujian UU Pembentukan Kota Tual Provinsi Maluku,untuk pertama kalinya beberapa kesatuan MHA menggunakan haknya sebagai Pemohon di Mahkamah Konstitusi. Setelah menjalani beberapa proses persidangan, ternyata Para Pemohon tidak terbukti sebagai Kepala Kesatuan MHA. Namun demikian, Putusan Perkara tersebut melahirkan beberapa hal baru atau digunakan sebagai landmark decision dalam pemaknaan dan kriteria Kesatuan MHA antara lain yaitu Mahkamah memberikan penafsiran tentang Pasal 18B ayat (2) UUD 1945 terkait dengan pengakuan dan penghormatan terhadap Kesatuan Masyarakat Hukum Adat. Hal ini lah yang disebut Achmad Sodiki (Sodiki, 2012:3) sebagai Politik Hukum Mahkamah Konstitusi. Politik Hukum Mahkamah Konstitusi yaitu politik hukum konstitusionalitas perkara yang diajukan ke Mahkamah dan pertimbangan hukumnya menggunakan penafsiran konstitusi yang memuat aspek filosofis, yuridis dan sosiologis. Oleh karena itu, tolak ukur untuk menilai kualifikasi Pemohon sebagai kesatuan Kesatuan Masyarakat Hukum Adat pada perkara-perkara selanjutnya didasarkan pada Putusan Nomor 31/PUU-V/2007 ini. Hal itu dapat dilihat dari pertimbangan Hukum Mahkamah, yaitu:
[3.15.1] Menimbang menurut kenyataannya, kesatuan Kesatuan Masyarakat Hukum Adat di Indonesia dapat dibedakan atas kesatuan Kesatuan Masyarakat Hukum Adat yang bersifat (i) teritorial, (ii) genealogis, dan (iii) fungsional. Ikatan kesatuan Kesatuan Masyarakat Hukum Adat yang besifat genealogis ditentukan berdasarkan kriteria hubungan keturunan darah, sedangkan ikatan Kesatuan 
Masyarakat Hukum Adat yang bersifat fungsional didasarkan atas fungsi-fungsi tertentu yang menyangkut kepentingan bersama yang mempersatukan Kesatuan Masyarakat Hukum Adat yang bersangkutan dan tidak tergantung kepada hubungan darah ataupun wilayah, seperti Subak di Bali. Sementara itu, kesatuan Kesatuan Masyarakat Hukum Adat yang bersifat teritorial bertumpu pada wilayah tertentu di mana anggota kesatuan Kesatuan Masyarakat Hukum Adat yang bersangkutan hidup secara turun-temurun dan melahirkan hak ulayat yang meliputi hak atas pemanfaatan tanah, air, hutan, dan sebagainya.

[3.15.2] Menimbang bahwa oleh karena Pasal 18B ayat (2) UUD 1945 berbunyi, "Negara mengakui dan menghormati kesatuankesatuan Kesatuan Masyarakat Hukum Adat beserta hak-hak tradisionalnya sepanjang masih hidup dan sesuai dengan perkembangan masyarakat dan prinsip Negara Kesatuan Republik Indonesia, yang diatur dalam undang-undang”, maka Mahkamah memandang perlu untuk menentukan kriteria atau tolok ukur terpenuhinya ketentuan Undang-Undang Dasar dimaksud yaitu bahwa kesatuan Kesatuan Masyarakat Hukum Adat tersebut:

a. Masih hidup;

b. Sesuai dengan perkembangan masyarakat;

c. Sesuai dengan prinsip Negara Kesatuan Republik Indonesia; dan

d. Ada pengaturan berdasarkan undangundang.

Kemudian Mahkamah menjelaskan lebih lanjut bahwa suatu kesatuan Kesatuan Masyarakat Hukum Adat untuk dapat dikatakan secara de facto masih hidup (actual existence) baik yang bersifat teritorial, genealogis, maupun yang bersifat fungsional setidak-tidaknya mengandung unsur-unsur (i) adanya masyarakat yang warganya memiliki perasaan kelompok (ingroup feeling); (ii) adanya pranata pemerintahan adat; (iii) adanya harta kekayaan dan/atau bendabenda adat; dan (iv) adanya perangkat norma Hukum adat. Khusus pada kesatuan Kesatuan Masyarakat Hukum Adat yang bersifat teritorial juga terdapat unsur (v) adanya wilayah tertentu.

Selanjutnya disebutkan kriteria KMHA yang sesuai dengan perkembangan masyarakat apabila Keberadaannya telah diakui berdasarkan undang-undang yang berlaku sebagai pencerminan perkembangan nilai-nilai yang dianggap ideal dalam masyarakat dewasa ini, baik undangundang yang bersifat umum maupun bersifat sektoral, seperti bidang agraria, kehutanan, perikanan, dan lain-lain maupun dalam peraturan daerah serta Substansi hak-hak tradisional tersebut diakui dan dihormati oleh warga kesatuan masyarakat yang bersangkutan maupun masyarakat yang lebih luas, serta tidak bertentangan dengan hak-hak asasi manusia.

Dengan demikian, batasan-batasan yang diberikan MK seyogyanya dipandang sebagai kriteria acuan suatu KMHA yang sah di mata hukum. Hal ini menjadi sangat penting tatkala membentuk peraturan perundang-undangan terkait KMHA. Definisi dan kriteria KMHA haruslah jelas untuk mencegah adanya penyalahgunaan kepentingan-kepentingan KMHA dan mempertegas kedudukan KMHA sebagai subjek hukum dimana hak-haknya perlu dilindungi oleh Negara.

Walaupun Mahkamah Konstitusi memberikan batasan-batasan yang sangat jelas dan tegas mengenai kriteria Kesatuan Masyarakat Hukum Adat, namun dalam beberapa putusannya MK memberikan perlindungan terhadap KMHA, antara lain:

(1) Putusan No. 35/PUU-X/2012 tentang Pengujian Undang-Undang Nomor 41 Tahun 1999 tentang Kehutanan bertanggal 6 Mei 2013 dimana amar putusannya mengabulkan sebagian permohonan Pemohon.

Pada perkara ini, para Pemohon terdiri dari Persekutuan Aliansi Masyarakat Adat Nusantara, Kesatuan Masyarakat Hukum Adat Kenegerian Kuntu yang berada di Kabupaten Kampar, Provinsi Riau dan Kesatuan Masyarakat Hukum Adat Kasepuhan Cisitu. Permohonan ini mempunyai 2 (dua) isu hukum penting yaitu, Pertama, terkait kedudukan hutan adat yang dikategorikan dalam hutan negara, kedua, Pengakuan bersyarat tentang keberadaan KMHA.

Dalam Putusannya, Mahkamah menggunakan pertimbangan yang berkaitan dangan prinsip kesejahteraan umum dikaitkan dengan pentingnya pengakuan masyarakat Hukum adat. Mahkamah berpendapat, "...Sebagai subjek Hukum di dalam suatu masyarakat yang telah menegara maka Kesatuan Masyarakat Hukum Adat haruslah mendapat perhatian sebagaimana subjek Hukum yang lain ketika Hukum hendak mengatur, terutama mengatur dalam rangka 
pengalokasian sumber-sumber kehidupan. Terkait dengan hal tersebut, UUD 1945 telah menentukan dasar-dasar konstitusionalnya, sebagaimana disebutkan dalam Pasal 33 ayat (2), ayat (3), dan ayat (4) UUD 1945...".

Dalam pertimbangan tersebut, dapat dikatakan MK telah mengaitkan prinsip kesejahteraan umum dan prinsip perekonomian nasional yang dianut oleh konstitusi, yaitu dalam Pasal 33 UUD 1945. Hal ini berarti pengakuan masyarakat Hukum adat sangat berkaitan dengan hak-hak alam di dalam penguasaan sumber daya alam. Selain itu, Mahkamah menegaskan bahwa keberadaan hutan adat merupakan satu kesatuan yang tidak terpisahkan dengan wilayah hak ulayat dari suatu KMHA sebagai akibat pengakuan Hukum Adat sebagai "living law". Oleh karena itu, menempatkan hutan adat sebagai bagian dari hutan negara merupakan pengabaian terhadap hak-hak Kesatuan Masyarakat Hukum Adat.

Dapat dikatakan bahwa pertimbangan putusan tersebut pada akhirnya memberikan batasan dan pemahaman yang jelas mengenai masyarakat Hukum adat yang perlu diakui hakhaknya. Karena pada pokoknya MK juga mempertimbangkan bahwa tidak semua kesatuan masyarakat Hukum adat dapat bertahan maupun dipertahankan. Untuk tetap hidup dan diakui, masyarakat hukum adat harus memenuhi faktor sepanjang masih hidup dan sesuai dengan perkembangan masyarakat, karena hukum adat pada umumnya merupakan hukum yang tidak tertulis dan merupakan living law, artinya merupakan hukum yang diterima (accepted) dan dijalankan (observed) serta ditaati oleh masyarakat yang bersangkutan karena memenuhi rasa keadilan bagi mereka dan sesuai serta diakui oleh konstitusi. Keberadaan masyarakat hukum adat yang sudah tidak diakui lagi atau tidak sesuai dengan kebutuhan masyarakat maupun kebutuhan nasional, menurut MK juga tidak diperlukan karena pada dasarnya, Kesatuan Masyarakat Hukum Adat cepat atau lambat juga akan mengalami perubahan seiring dengan perkembangan masyarakat tersebut, bahkan dapat pula lenyap sifat dan tanda-tandanya. Perubahan tersebut dapat berdampak positif maupun negatif bagi masyarakat yang bersangkutan. Untuk mencegah terjadinya dampak negatif, UUD 1945 memerintahkan keberadaan dan perlindungan kesatuan-kesatuan Kesatuan Masyarakat Hukum Adat supaya diatur dalam Undang-Undang, agar dengan demikian menjamin adanya kepastian hukum yang berkeadilan.

Putusan MK tersebut melahirkan kognisi positif dalam perlindungan KMHA yang menimbulkan konsekuensi terhadap pemerintah pusat dan daerah untuk segera membentuk peraturan-peraturan teknis dibawah UU terkait KMHA untuk menjalankan Putusan MK. Beberapa peraturan perundang-undangan teknis sebagai bagian dari implementasi Putusan MK No.35/PUU-X/2012,yaitu:

(a) Peraturan Menteri Kehutanan No. P.62/MenhutII/ 2013 tentang Perubahan Atas Peraturan Menteri Kehutanan No. P.44/Menhut-II/2012 tentang Pengukuhan Kawasan Hutan.

(b) Permendagri No.52 Tahun 2014 tentang Pedoman Pengakuan dan Perlindungan Masyarakat Hukum Adat.

(c) Peraturan Bersama Menteri Dalam Negeri RI, Menteri Kehutanan RI, Menteri Pekerjaan Umum RI, dan Kepala Badan Pertanahan Nasional RI Nomor 79 Tahun 2014, Nomor PB.3/ Menhut-11/2014, Nomor 17/PRT/M/2014, Nomor 8/SKB/X/2014 tentang Tata Cara Penyelesaian Penguasaan Tanah yang Berada di Dalam Kawasan Hutan.

(d) Peraturan Menteri Lingkungan Hidup dan Kehutanan Republik Indonesia Nomor: P.32/Menlhk-Setjen/2015 tentang Hutan Hak.

Sedangkan dalam tataran daerah misalnya saja yaitu setelah Putusan MK No.35/PUUX/2012, Pemerintah Kabupaten Jayapura-Papua mengeluarkan Surat Keputusan (SK) Bupati No.319 Tahun 2014 tentang Pengakuan dan perlindungan Masyarakat Hukum Adat di Kabupaten Jayapura pada tanggal 24 Oktober 2014 dan tanggal tersebut diperingati sebagai Hari Kebangkitan Masyarakat Hukum Adat di Jayapura (Cahyaningrum, 2015:8). Sementara itu, Yance Arizona (Arizona, 2013: 5) memberikan contoh lebih banyak kebijakan dan peraturan mengenai pengakuan terhadap keberadaan dan hak masyarakat adat, antara lain:

(a) Keberadaan masyarakat adat. Jenis ini seperti Perda Morowali No. 13 Tahun 2012 tentang Pengakuan dan Perlindungan Masyarakat Hukum Adat Suku Wana.

(b) Kelembagaan adat. Jenis ini seperti Perda Kalimantan Tengah No. 16 Tahun 2008 tentang Kelembagaan Adat Dayak di Kalimantan Tengah. 
(c) Hak atas tanah dan hutan. Perda Lebak No. 32 Tahun 2001 tentang Perlindungan Atas Hak Ulayat Masyarakat Baduy. Selain itu juga Peraturan Gubernur Kalimantan Tengah No. 13 Tahun 2009 tentang Tanah Adat dan Hak-hak Adat di Atas Tanah serta SK Bupati Merangin No. 287 Tahun 2003 tentang Pengukuhan Bukit Tapanggan sebagai Hutan Adat Masyarakat Hukum Adat Desa Guguk Kecamatan Sungai Manau Kabupaten Merangin.

(d) Hukum adat dan peradilan adat. Jenis ini seperti Peraturan Gubernur Sulawesi Tengah No. 43 Tahun 2013 tentang Pedoman Peradilan Adat Sulawesi Tengah. Peraturan Gubernur Kalteng No. 13 Tahun 2009 tentang Tanah Adat dan Hak-hak Adat di Atas Tanah yang telah diubah dengan Peraturan Gubernur No. 4 Tahun 2012. Peraturan-peraturan itu mengatur mengenai kelembagaan adat dan hak masyarakat adat atas tanah.

(2) Putusan No.95/PUU-XII/2014 dalam perkara Pengujian Undang-Undang Nomor 18 Tahun 2013 tentang Pencegahan dan Pemberantasan Perusakan Hutan dan Undang-Undang Nomor 41 Tahun 1999 tentang Kehutanan

Dalam perkara ini, para Pemohon mengajukan pengujian terhadap 19 (sembilan belas) ketentuan dalam Undang-Undang Nomor 18 Tahun 2013 tentang Pencegahan dan Pemberantasan Perusakan Hutan (UU P3H) dan 4 (empat) ketentuan dalam Undang-Undang Kehutanan. Para pemohon mendalilkan bahwa dengan berlakunya sejumlah ketentuan dalam UU P3H dan UU Kehutanan tersebut telah berdampak kepada kriminalisasi terhadap masyarakat yang berada di dalam dan sekitar kawasan hutan, ketidakpastian Hukum mengenai status kawasan hutan yang menimbulkan konflik tenurial kehutanan, dan kondisi hutan yang semakin memburuk. Setelah menyatakan para Pemohon memiliki kedudukan hukum, kemudian dalam pertimbangan hukum pokok perkaranya, Mahkamah berpendapat bahwa penetapan tindak pidana terhadap suatu rangkaian perbuatan dalam lalu lintas kehidupan masyarakat harus memperhatikan tujuan pembangunan nasional yaitu mewujudkan masyarakat adil dan makmur. Hal ini dilakukan untuk menanggulangi kejahatan demi kesejahteraan dan perlindungan masyarakat serta pengayoman masyarakat secara menyeluruh dan utuh, tanpa membedakan perlindungan terhadap kelompok masyarakat tertentu.

Sementara itu, Mahkamah juga mengabulkan permohonan para Pemohon untuk memberikan pengecualian terhadap masyarakat yang hidup di dalam dan di sekitar kawasan hutan dan tidak ditujukan untuk kepentingan komersial agar tidak dilarang untuk menebang pohon atau memanen atau memungut hasil hutan di dalam hutan tanpa memiliki hak atau izin dari pejabat yang berwenang, Mahkamah berpendapat bahwa memang seharusnya masyarakat yang hidup secara turun temurun di dalam hutan yang membutuhkan sandang, pangan, dan papan untuk kebutuhan sehari-hari dengan menebang pohon dan dapat dibuktikan tidak disalahgunakan untuk kepentingan pihak lain (komersial) sehingga bagi masyarakat tersebut tidaklah termasuk dalam larangan sebagaimana dimaksud dalam Pasal 50 ayat (3) huruf e UU Kehutanan sehingga tidak dapat dijatuhkan sanksi pidana terhadapnya. Sebab, akan terjadi paradoks apabila di satu pihak kita mengakui masyarakat yang hidup secara turun temurun di dalam hutan dan membutuhkan hasil hutan namun di lain pihak masyarakat tersebut diancam dengan Hukuman. Sebaliknya, negara justru harus hadir memberikan perlindungan terhadap masyarakat demikian. Dengan demikian permohonan para Pemohon sepanjang mengenai pengecualian terhadap masyarakat yang hidup di dalam hutan dan tidak ditujukan untuk kepentingan komersial, beralasan menurut Hukum untuk sebagian sepanjang yang berkaitan dengan dan hanya terhadap masyarakat yang hidup secara turun temurun di dalam hutan, bukan yang berada di sekitar kawasan hutan sebab pemaknaan "di sekitar kawasan hutan" sangatlah berbeda dengan masyarakat yang hidup di dalam hutan.

Mahkamah dalam putusan ini mengadopsi sejenis konsep affirmatife action dengan dasar bahwa perlindungan terhadap masyarakat adat merupakan kewajiban pemerintah, dan bahwa ada pengakuan terhadap kelompok masyarakat yang perlu pengecualian terhadap penegakan hukum yang berdampak terhadap hak adat mereka. Terdapat adanya penegasan dalam putusan ini bahwa negara tidak dapat memungkiri keberadaan kelompok masyarakat yang telah hidup dan bermukim di dalam suatu kawasan secara turun temurun yang mau tidak mau terdampak oleh adanya pembangunan dan 
penegakan Hukum, sehingga perlindungan terhadap masyarakat ini juga merupakan amanat konstitusi. Sebelum bertindak dalam menegakkan hukum dan mengimplementasikan pembangunan, pemerintah perlu mempertimbangkan komunitas masyarakat yang telah lama bermukim di sana, khususnya mereka yang hidupnya akan benarbenar terancam apabila hak atas sumber daya alam mereka dihalangi.

\section{Kesimpulan}

UUD 1945 sebagai konstitusi Indonesia memberikan jaminan perlindungan kepada masyarakat hukum adat, termasuk hak untuk mengembangkan dan memelihara nilai-nilai budayanya. Secara eksplisit Pasal 18B ayat (2) UUD 1945 telah menyebutkan kesatuan masyarakat hukum adat sebagai salah satu yang harus dihormati dan dilindungi oleh negara. Pasal ini yang kemudian menjadi landasan bagi pengakuan terhadap hak-hak kesatuan masyarakat hukum adat di Indonesia. Kesatuan masyarakat Hukum adat kemudian disebutkan di beberapa UU dan peraturan di bawahnya. Namun demikian, belum terdapat undang-undang yang terintegrasi mengenai kategori masyarakat Hukum adat apa saja yang dapat diakui sebagai masyarakat Hukum adat. Padahal hal tersebut sangat dibutuhkan mengingat begitu pentingnya memberikan pemisahan tegas antara Kesatuan Masyarakat Hukum Adat yang memiliki hak sebagai subjek Hukum dan Kesatuan Masyarakat Adat yang tidak dapat diposisikan sebagai subjek hukum. Pengintegrasian masyarakat hukum adat bukan hal yang sederhana, namun membutuhkan pemikiran yang serius mengenai implementasi dan implikasi dari pengintegrasian berbagai sistem hukum adat ke dalam sistem Hukum Nasional.

Peranan Mahkamah Konstitusi terhadap masyarakat Hukum Adat dapat ditelusuri dari beberapa Putusannya di mana putusanputusannya menjadi landmark decision dalam melindungi eksistensi Kesatuan Masyarakat Hukum Adat. Politik Hukum Mahkamah Konstitusi juga memberikan salah satu batasan penting untuk mendefinisikan masyarakat hukum adat dan memahami pentingnya menegaskan masyarakat adat yang mana yang masih relevan untuk diakui sebagai masyarakat hukum adat, serta masyarakat adat yang mana yang tidak dapat memenuhi syarat sebagai subjek hukum. Pembatasan serta penegasan ini penting karena dibalik pengakuan terhadap komunitas adat di Indonesia, pemberian hak masyarakat adat untuk mengimplementasikan aturan hukum tersendiri di luar hukum nasional yang kebablasan dapat menimbulkan ketidakpastian hukum, dan bahkan chaos di dalam penegakan hukum.

Dalam merumuskan apapun aturan yang dibutuhkan dalam mengakui masyarakat hukum adat dan pengintegrasiannya dalam hukum positif, pihak pembentuk undang-undang perlu merujuk kepada putusan Mahkamah Konstitusi yang telah menguraikan dan menafsirkan konstitusionalitas masyarakat hukum adat serta batasan-batasan dalam memberikan pengakuan terhadap masyarakat hukum adat. Sebagian akan pemikiran tersebut tidak hanya terdapat pada bagian Amar Putusan Mahkamah Konstitusi, namun lebih terurai dan tergambar pada pertimbangan hukum, sehingga pembentuk undang-undang diharapkan untuk lebih agresif dalam membedah putusan Mahkamah Konstitusi bukan hanya sekedar melaksanakan Amar Putusan, namun juga mengkaji serta mendalami pertimbangan Hukum Mahkamah Konstitusi dalam rangka memperkaya khazanah konstitusional masyarakat hukum adat dan original intent dari putusan tersebut.

Sementara itu, dalam tataran praktis perlu adanya harmonisasi peraturan perundangundangan baik pemerintah pusat dan daerah khususnya antara Kementerian Lingkungan Hidup dan Kehutanan dengan Badan Pertanahan Nasional serta Kementerian atau Instansi terkait lainnya sehingga tidak terjadi tumpang tindih antara peraturan teknis satu dengan lainnya.

\section{Daftar Pusataka}

Abdurrahman, Tim Pusat Penelitian Dan Pengembangan Sistem Hukum Nasional Badan Pembinaan Hukum Nasional Kementerian Hukum Dan Hak Asasi Manusia RI. (2015). Draft Laporan Pengkajian Hukum Tentang Mekanisme Pengakuan Kesatuan Masyarakat Hukum Adat. Jakarta. (www.bphn. go.id/data/ documents/mekanisme_pengakuan_masy _hkm_adat.pdf, diakses pada tanggal 10 Oktober 2016).

Achmad. Sodiki. (2012). Politik Hukum Dalam Konstruksi Ilmu Hukum. Makalah dalam Kongres Ilmu Hukum: Refleksi dan Rekonstruksi Ilmu Hukum Indonesia, Asosiasi Sosiologi Hukum 
Indonesia bekerjasama dengan Fakultas Hukum Universitas Diponegoro. Semarang.

Alting, Husen. (2010). Dinamika Hukum dalam Pengakuan dan Perlindungan Hak Kesatuan Masyarakat Hukum Adat Atas Tanah. Yogyakarta: LaksBang PRESSindo.

Arizona. Yance. (2013). Peluang Hukum Implementasi Putusan MK 35 ke dalam Konteks Kebijakan Pengakuan Masyarakat Adat di Kalimantan Tengah. Makalah disampaikan dalam Lokakarya "Fakta Tekstual (Quo Vadis) Hutan Adat Pasca Putusan MK No.35/PUU-X/2012“. Palangkaraya. Diakses dari http://www. lifemosaic.net/images/uploads/Resourc es/Docs\%20BI/Yance_ArizonaPeluang_Hukum_Implementasi_Putusa n_MK_35.pdf, tanggal 7 April 2017.

Asshiddiqie, Jimly. (2015). Gagasan Konstitusi Sosial: Institusionalisasi dan Konstitusionalisasi Kehidupan Sosial Masyarakat Madani, Jakarta: Pustaka LP3ES.

Asshiddiqie, Jimly. (2003). Konsolidasi Naskah UUD 1945. Jakarta: Penerbit Yarsif Watampoe.

Cahyaningrum, Dian. (2015). Implikasi Putusan Mahkamah Konstitusi Mengenai Status Hutan Adat Sebagai Hutan Hak, Jurnal Kajian DPR Vol.20 No.1, Maret 2015 hal.1-16. Diakses dari https://jurnal. dpr.go.id/index.php/kajian/article/view/ 566/461, tanggal 7 April 2017.
Indrati, Maria Farida. (2007). Ilmu Perundangundangan: Jenis, Fungsi dan Materi Muatan. Jogjakarta: Kanisius.

Latif. (2014). Mata Air Keteladanan Pancasila dalam Perbuatan. Bandung: Mizan

Lubis, Solly. (2014). Politik Hukum dan Kebijakan Publik. Bandung: Mandar Maju.

Setiady, Tolib. (2013). Intisari Hukum Adat Indonesia (Dalam Kajian Kepustakaan). Bandung: Penerbit Alfabeta.

Thontowi, Jawahir, dan Pusat Penelitian dan Pengkajian Perkara, Pengelolaan Teknologi Informasi dan Komunikasi Mahkamah Konstitusi Republik Indonesia dan Centre for Local Law Devolepment Studies (CLDS) Fakultas Hukum Universitas Islam Indonesia. (2012). Laporan Hasil Penelitian Aktualisasi Masyarakat Hukum Adat (MHA): Perspektif Hukum dan Keadilan Terkait Dengan Status MHA dan Hak-hak Konstitusionalnya. Jakarta.

Tim Penyusun Hukum Acara MK. (2010). Hukum Acara Mahkamah Konstitusi, Jakarta: Sekretariat Jenderal dan Kepaniteraan MK RI.

Wignjosoebroto, Soetandyo. (2002). Hukum, Paradigma, Metode, dan Dinamika Masalahnya. Jakarta: Elsam

Wheare, KC. (2003). Konstitusi-Konstitusi Modern, terj. Muh. Hardani. Surabaya: Pustaka Eureka. 
